\title{
Comprehensive Investigation on the Potential of Fly Ash from New Source as Construction Material
}

\author{
Antoni $^{{ }^{*}}$, Hartono, F. ${ }^{1}$, Tanuwijaya, S. ${ }^{1}$, Wijaya, K. ${ }^{1}$, Vianthi, A. ${ }^{1}$, and Hardjito, D. ${ }^{1}$
}

\begin{abstract}
Fly ash has been highly advocated to be re-utilized as a construction material. The most common utilization is to partially replace cement in a low-percentage scheme. However, there are several other schemes available to potentially use fly ash as binder in concrete that have not been widely exercised, especially those utilizing it in high to very high volume. In those schemes, highvolume fly ash (HVFA) concrete might use more than 50\% fly ash to replace cement. To exploit its self-cementing properties, with or without the addition of other compounds, such as calcium hydroxide, fly ash might be used in very high percentage of cement replacement. In geopolymeric system, fly ash acts as the precursor of a stable binder, with the presence of highly alkaline solution. This paper demonstrates a model to investigate the potential of fly ash in several binder systems. The results show that fly ash from a good source can be utilized as an alternative binder in several different schemes.
\end{abstract}

Keywords: Fly ash; alternative binder; pozzolan; HVFA; self-cementing; geopolymer; calcium hydroxide.

\section{Introduction}

Coal-fired power plants will remain the dominant power supply in Indonesia for several decades to come [1]. The geography of the archipelagic nation and the abundant availability of locally sourced coal are the main reasons for the construction of many coal-fired power plants throughout the country [2]. Many new power plants have been recently commissioned, for example: Tanjung Awar-Awar plant in Tuban, Sudimoro plant in Pacitan, Jawa-7 plant in Banten, and Jawa-8 plant in Cilacap. Many more are in the construction or planning stage. Although the Indonesian Government has pledged to stop building coalfired power plants by 2025, the current power plants will produce electrical energy and emit fly ash, bottom ash, and other greenhouse gases for decades [3].

Fly ash is a waste, generated from the coal burning process and has been found to be beneficial as cement replacement in concrete [4]. The replacement of Portland cement in concrete would reduce the production of cement, which is a major contributor to $\mathrm{CO}_{2}$ gas emissions and, hence, climate change [5]. The spherical shape of the fly ash benefits the workability of the concrete mixture while the pozzolanic reaction of fly ash and the calcium hydroxide in concrete increase the concrete strength and density [6,7].

${ }^{1}$ Department of Civil Engineering, Petra Christian University, Jl. Siwalankerto 121-131, Surabaya 60236, INDONESIA

*Corresponding author; Email: antoni@petra.ac.id

Note: Discussion is expected before November, $1^{\text {st }} 2021$, and will be published in the "Civil Engineering Dimension", volume 24, number 1, March 2022.

Received 27 June 2021; revised 04 July 2021; accepted 17 July 2021.
Fly ash can be characterized physically and chemically. Physical properties of fly ash are determined by its density, particle shape, and distribution while the chemical properties of fly ash are determined from its chemical compound, crystal structure, and reactivity. Both physical and chemical properties are important to determine the quality of fly ash [8].

The coal-fired power plant design influences the burning process that determines the quality of the fly ash. Power plants with a pulverized coal combustion (PCC) process generate spherical-shaped ash, while power plants with a circulating fluidized bed combustion (CFBC) system generate irregular-shaped ash that requires higher water content in the concrete mixture [9,10]. Therefore, the potential of a power plant as a good source of fly ash to be used in concrete as a binder system needs to be ascertained.

Because fly ash is a waste of the burning process, its quality also varies with time due to differences in coal source, coal combustion temperature, and other variables. Several rapid tests on determining the quality of fly ash had been suggested [11], i.e., loss-on-ignition (LOI), pH, percent retained on sieve \#325 (45 $\mu \mathrm{m})$, and normal consistency. High LOI content reflects high unburned carbon in fly ash, which increases water demand in the mixture and interferes with the hydration reactions in cement $[12,13]$. Thus, the LOI of fly ash may affect concrete workability and compressive strength. The $\mathrm{pH}$ indicates the reactivity of the fly ash and its alkali content corresponding to the calcium oxide content [14]. Fly ash with high pH (> 11) could have a shorter initial setting time, with the possibility of flash setting of the mixture. However, 
high calcium oxide content also can increase the compressive strength with the possibility of selfcementing behavior. Meanwhile, normal consistency tests indicate the water requirements of the fly ash compared to the cement paste mixture. Lower normal consistency than the cement paste mixture resulted that the more fly ash used in the mixture, the less water is needed for the same workability.

Utilization of fly ash as cement replacement in making concrete can be done in several binder systems. The most common system replaces up to $30 \%$, by mass, of Portland cement in concrete. The low utilization rate of the fly ash is mostly due to the variation of fly ash obtained from different power plants. At lower replacement levels, the uncertainties of the fly ash quality are manageable without any prior testing on the fly ash itself [13]. At higher replacement ratios, the quality assurance of the fly ash becomes the determining factor in producing good concrete. High-volume fly ash (HVFA) aims to replace more than $50 \%$ of the Portland cement used and still could provide similar long-term strength [15-17]. Reduced water-to-binder ratio and lower temperature rise are the main advantages of this mixture, given the required fly ash quality assurance [18-21].

At higher than the $90 \%$ replacement ratio, the role of Portland cement as binder is greatly diminished in order to provide enough bonding in concrete. In some instances, concrete using only fly ash with selfcementing properties still can provide reasonable strength [22] and can be used, for example, as controlled low-strength material (CSLM) or soil stabilization $[23,24]$. The role of Portland cement in the mixture is as an admixture to provide initial strength and increase the internal temperature that accelerates the reaction of fly ash in concrete. Fly ash with very high calcium oxide content could have selfcementing properties that produce normal-strength concrete at low water-to-cement ratios [25].

Fly ash could also replace $100 \%$ of Portland cement in concrete with modification on the binder system. Roman concrete was successfully produced by reacting calcined clay and calcium hydroxide, and has last for millennia [26]. Therefore, fly ash could also reacts with an external calcium hydroxide source to produce strong and durable concrete [27-29]. Even though the reaction rate of fly ash and calcium hydroxide is quite slow, the resultant binder could be used as an alternative in making concrete when there is a source of calcium hydroxide or in remote locations where Portland cement is not readily available.

Geopolymer concrete is produced by activating an alumina-silicate source with an alkaline solution to produce hardened concrete using fly ash as the precursor material [30]. Utilizing low-calcium fly ash as geopolymer source material could produce a good quality geopolymer; however, it needs an elevated temperature for the strength development to occur. Meanwhile, using high-calcium fly ash as precursor for geopolymer can cause the geopolymer to harden naturally at room temperature, but it is troubled by the occasional occurrence of flash setting [31,32]. The ratio of alkaline liquid (sodium silicate and sodium hydroxide) adjusted to the precursor material is the main variable in making successful geopolymer, in addition to the quality of the fly ash itself [33-35].

This study aims to show an experimental investigation of the potential quality of fly ash obtained, especially from new and unknown power plant sources as a binder for construction material. The fly ash used in this study was obtained from the Sudimoro power plant, Pacitan, East Java, Indonesia. The Sudimoro power plant began operations in 2014, utilizing a pulverized coal combustion (PCC) system with two boilers and coal sourced from East Kalimantan, Indonesia. It generates about 18.7 tons of fly ash and 7.2 tons of bottom ash daily as recorded in July 2020. Its fly ash and bottom ash has not been widely utilized in the construction industry yet due to the remote location of the plant and scarcity of research on this fly ash. First, the properties of the fly ash was investigated by material test, and then the potential of this fly ash as a replacement for Portland cement was investigated in several binder systems, namely, pozzolan, HVFA, self-cementing, fly ashcalcium hydroxide $(\mathrm{Fa}-\mathrm{Ca})$ system, and geopolymer in the mortar mixture. The study of the same fly ash sample in multiple binder systems can assess the value of the fly ash, so that its usage can be further promoted.

\section{Experimental Methods}

\section{Materials}

Two fly ash samples were collected from a pulverized coal combustion power plant in Sudimoro, Pacitan, East Java, Indonesia. One was collected in an open area (A) and the other fresh from the boiler (B). The obtained samples are shown in Figure 1. Despite being taken from the same power plant, the two fly ash samples each showed different physical qualities. Fly ash A had darker color and showed many little clumps. This was because it had reacted with the humidity and rain. Fly ash B was directly collected from the boiler and still had a powdery form. Therefore, the initial collection of the fly ash already affected its quality. This study used only fly ash B as fly ash A was deemed unsuitable. 


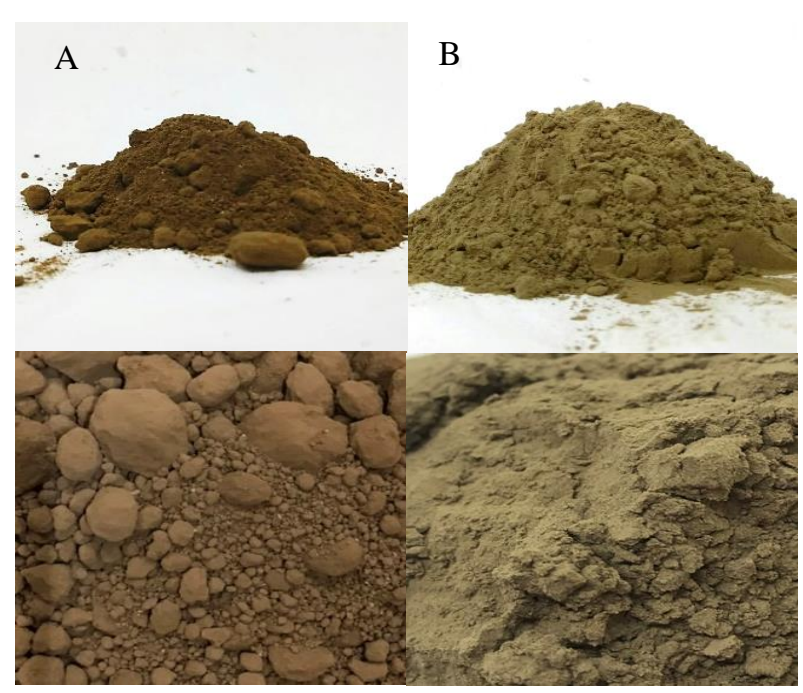

Figure 1. Fly Ash Obtained from Sudimoro Power Plant

Ordinary Portland cement (OPC) was obtained in bulk form from Dynamix Plant, Tuban, Indonesia. Silica sand from the Tuban quarry was used as fine aggregate in making the mortars. To ensure consistent grading of the sand, it was graded by sieve analysis to obtained a fineness modulus (FM) of 2.05 (modified from the ASTM C778 [36]) as detailed in Table 1. The sand needs to be graded as the particle distribution of the natural sand could vary and affect the workability of the mixture. The superplasticizer used was polycarboxylate-based Sika Viscocrete 1003 and the water was demineralized. Calcium hydroxide was produced in the laboratory manually by slaking fresh calcium oxide in water, mixing it thoroughly, and leaving it for 24 hours. Then, the calcium hydroxide paste was dried in an oven and milled into powdery form. The calcium oxide was obtained from Puger village, Jember, East Java, Indonesia. The sodium hydroxide flake and sodium silicate liquid were obtained from a local chemical store. The sodium hydroxide was purity $94 \%$ and the sodium silicate liquid used was grade BE 52 , with free water content of $40 \%$ (measured by oven-drying the liquid at $105^{\circ} \mathrm{C}$ for 24 hours). The $8 \mathrm{M} \mathrm{NaOH}$ solution was made from $320 \mathrm{~g}$ of sodium hydroxide dissolved in demineralized water to make a $1000 \mathrm{~mL}$ solution. The $\mathrm{NaOH}$ solution was then cooled to room temperature before use.

Table 1. Silica sand Particle Size Distribution

\begin{tabular}{ccc}
\hline $\begin{array}{c}\text { Sieve Sizes } \\
(\mathrm{mm})\end{array}$ & $\begin{array}{c}\text { Cumulative } \\
\text { Retained } \\
\text { (wt.\%) }\end{array}$ & $\begin{array}{c}\text { ASTM C778 } \\
\text { Requirements } \\
\text { (wt.\%) }\end{array}$ \\
\hline 1.180 & 0 & 0 \\
0.600 & 8.8 & $0-4$ \\
0.425 & 46.6 & $25-35$ \\
0.300 & 54.4 & $70-80$ \\
0.150 & 95.5 & $96-100$ \\
Base & 100 & 100 \\
\hline FM & $\mathbf{2 . 0 5}$ & $1.91-2.19$ \\
\hline
\end{tabular}

\section{Testing Procedures}

The obtained fly ash was tested for its quality. For new sources of fly ash, several analyses were conducted, both physically and chemically. The chemical analysis utilized X-ray fluorescence (XRF) and X-ray diffraction (XRD) methods to observe the chemical composition of the fly ash. However, those tests are expensive and time-consuming. Rapid indicators for the quality of the fly ash, such as the specific gravity, $\mathrm{pH}$, normal consistency, and percentage retained in $45 \mu \mathrm{m}$ sieve, can be useful tools in determining the variation of the fly ash obtained [11]. The fly ash $\mathrm{pH}$ was determined by adding $20 \mathrm{~g}$ of fly ash into $80 \mathrm{~mL}$ distilled water according to ASTM D5239 [37]. Normal consistencies of cement and fly ash paste were measured using Vicat apparatus according to ASTM C187 [38]. Visual inspection on the fly ash appearance was carried out to observe the possible variation of the fly ash obtained. If changes of color or appearance were observed, then the suitability of the fly ash required further evaluation.

Mortar mixture composition needs to be determined based on the normal consistency test. PCC fly ash normally has reduced water requirement for similar workability compared to OPC. When higher normal consistency is observed, the fly ash could have different particle shape or high LOI content. The water-to-cement ratio of the mortar was then determined as low as possible. The compressive strength of the mortar mixture was deemed comparable when the water-to-binder ratios were similar and the workability controlled. Polycarboxy late-based superplasticizer was used to increase the workability of the mortar mixture with a determined water-to-cement ratio to the same target flow diameter of $15 \pm 1 \mathrm{~cm}$ in the mortar flow table test according to ASTM C1437 [39]. The ratio of superplasticizer dosage to the total binder used was recorded as the superplasticizer demand in weight percent.

The initial setting time of the mortar mixture was tested using a mortar penetrometer according to ASTM C403 [40]. Time to reach penetration resistance of 500 psi or $3.45 \mathrm{MPa}$ was recorded as the initial setting time. The temperature evolution of fly ash cement combination was also recorded for up to 48 hours on the paste mixture by preparing the same mixture as the mortar but without the use of sand and superplasticizer. The paste was prepared in a $200 \mathrm{~mL}$ plastic cup and kept in a Styrofoam container with thermocouple sensor.

The compressive strength test on the mortar specimens were done on a $5 \times 5 \times 5 \mathrm{~cm}^{3}$ cube specimen according to ASTM C109 [41]. Three replications were performed on each testing age of $3,7,14,28$, and 56 days. 


\section{Mixture Composition and Specimen Preparation}

Mortar mixtures need to be made with fly ash as partial or full replacement of cement in several binder systems. Fly ash as cement replacement from 0-30\% by mass is called "pozzolan mortar." High-volume fly ash (HVFA) mortar uses fly ash as cement replacement from $40-80 \%$ by mass. Fly ash as cement replacement from $90-100 \%$ by mass is called "selfcementing mortar." At 100\% cement replacement, two binder systems can also be developed, namely, the fly ash-calcium hydroxide ( $\mathrm{Fa}-\mathrm{Ca})$ mortar, where the use of calcium hydroxide partially replaces the fly ash up to $40 \%$, and geopolymer mortar, where the fly ash is activated by the alkaline solution of sodium hydroxide and sodium silicate.

The water-to-binder ratio of the mortar mixture needs to be selected as low as possible in order to produce a cohesive mixture. For all mortar mixtures, the sandto-binder ratio was set at 2 by mass, using graded silica sand. The pozzolan mortar was investigated at water-to-binder ratios (w/b) of $0.3,0.35$, and 0.4 , with the cement replacement ratio of $0-30 \%$. The HVFA and self-cementing mortar used w/b of 0.3 . The mixture proportions of the pozzolan, HVFA, and self-cementing mortar are reported in Table 2.

The Fa-Ca binder used w/b of 0.4 due to the higher water requirement of the calcium hydroxide powder in the mixture. The calcium hydroxide replaced $30 \%$, $35 \%$, and $40 \%$ fly ash, by mass, in the mortar mixture.

Table 2. Mix Proportions for Pozzolan, HVFA, and Selfcementing Mortar

\begin{tabular}{lcrrrr}
\hline \multicolumn{1}{c}{ Code } & w/b & \multicolumn{1}{c}{$\begin{array}{c}\text { OPC } \\
(\mathrm{g})\end{array}$} & $\begin{array}{r}\text { Fly Ash } \\
(\mathrm{g})\end{array}$ & $\begin{array}{c}\text { Sand } \\
(\mathrm{g})\end{array}$ & $\begin{array}{c}\text { Water } \\
(\mathrm{g})\end{array}$ \\
\hline $3 \mathrm{P}-0 \%$ & & 1000 & 0 & & \\
$3 \mathrm{P}-10 \%$ & & 900 & 100 & 2000 & 300 \\
$3 \mathrm{P}-20 \%$ & 0.30 & 800 & 200 & & \\
$3 \mathrm{P}-30 \%$ & & 700 & 300 & & \\
\hline $3.5 \mathrm{P}-0 \%$ & & 1000 & 0 & & \\
$3.5 \mathrm{P}-10 \%$ & 0.35 & 900 & 100 & 2000 & 350 \\
$3.5 \mathrm{P}-20 \%$ & & 800 & 200 & & \\
$3.5 \mathrm{P}-30 \%$ & & 700 & 300 & & \\
\hline $4 \mathrm{P}-0 \%$ & & 1000 & 0 & & \\
$4 \mathrm{P}-10 \%$ & 0.40 & 900 & 100 & 2000 & 400 \\
4P-20\% & & 800 & 200 & & \\
4P-30\% & & 700 & 300 & & \\
H-40\% & & 600 & 400 & & \\
H-50\% & & 500 & 500 & & \\
H-60\% & 0.30 & 400 & 600 & 2000 & 300 \\
H-70\% & & 300 & 700 & & \\
H-80\% & & 200 & 800 & & \\
\hline S-90\% & & 100 & 900 & & \\
S-95\% & 0.30 & 50 & 950 & 2000 & 300 \\
S-100\% & & 0 & 1000 & & \\
\hline
\end{tabular}

Table 3. Mix Proportions for Fa-Ca System Mortar

\begin{tabular}{cccccc}
\hline Code & w/b & $\begin{array}{c}\mathrm{Ca}(\mathrm{OH})_{2} \\
(\mathrm{~g})\end{array}$ & $\begin{array}{c}\text { Fly Ash } \\
(\mathrm{g})\end{array}$ & $\begin{array}{c}\text { Sand } \\
(\mathrm{g})\end{array}$ & $\begin{array}{c}\text { Water } \\
(\mathrm{g})\end{array}$ \\
\hline $\mathrm{Ca}-30 \%$ & & 300 & 700 & & \\
$\mathrm{Ca}-35 \%$ & \multirow{2}{*}{0.4} & 350 & 650 & 2000 & 400 \\
$\mathrm{Ca}-40 \%$ & & 400 & 600 & & \\
\hline
\end{tabular}

Table 4. Mix Proportions for Geopolymer Mortar

\begin{tabular}{lccccccc}
\hline Code & $\begin{array}{c}\mathrm{Na}_{2} \mathrm{SiO}_{3} / \\
\mathrm{NaOH}\end{array}$ & w/b & $\begin{array}{c}{[8 \mathrm{M}]} \\
\mathrm{NaOH} \\
(\mathrm{g})\end{array}$ & $\begin{array}{c}\mathrm{Na}_{2} \mathrm{SiO}_{3} * \\
(\mathrm{~g})\end{array}$ & $\begin{array}{c}\mathrm{Fly} \\
\mathrm{Ash} \\
(\mathrm{g})\end{array}$ & $\begin{array}{c}\text { Sand } \\
(\mathrm{g})\end{array}$ & $\begin{array}{c}\text { Water } \\
(\mathrm{g})\end{array}$ \\
\hline $\mathrm{G}-2$ & 2 & & 96 & 320 & 1000 & 172 \\
$\mathrm{G}-2.5$ & 2.5 & 0.396 & 96 & 400 & 1000 & 2000 & 140 \\
G-3 & 3 & & 96 & 480 & 1000 & & 108 \\
\hline
\end{tabular}

* free water in the sodium silicate was measured at $40 \mathrm{wt} . \%$

The mixture compositions for the $\mathrm{Fa}-\mathrm{Ca}$ mortar are reported in Table 3. Geopolymer mortar was made with w/b of about 0.4 by considering the free water content in the sodium silicate and sodium hydroxide solution. The alkaline solution ratio of sodium silicate solution to the $8 \mathrm{M}$ sodium hydroxide solution was set at $2,2.5$, and 3 by mass. Table 4 lists the mixture proportions for the geopolymer mortar for $1000 \mathrm{~g}$ fly ash.

Superplasticizer was added to the mixture to control the workability of the fresh mortar to reach the target flow diameter. However, the addition of polycarboxylate-based superplasticizer was not done for the geopolymer mortar mixture due to the potential reduction of compressive strength with an increase of superplasticizer dosage.

The fresh mortar was then compacted into the cube molds to produce the specimens. There were two types of curing used for the mortar specimens: water immersion and elevated temperature curing. The mortar specimens with fly ash content of $0-80 \%$ were demolded one day after casting and cured in water immersion up to one day prior to the testing time. The self-cementing, $\mathrm{Fa}-\mathrm{Ca}$, and geopolymer mortar were oven-cured at $60^{\circ} \mathrm{C}$ for 24 hours in shrink-wrap plastic, demolded, kept in a sealed plastic bag, and placed in room temperature condition until testing. The elevated temperature for the $100 \%$ fly ash binder was intended to accelerate the reaction of the fly ash binder.

\section{Results and Discussions}

\section{Fly Ash Materials}

$\mathrm{X}$-ray fluorescence (XRF) analysis was used to determine the chemical composition of fly ash. The XRF results of the Pacitan fly ash are presented in Table 5. Results of fly ash from the Paiton power plant in East Java, Indonesia, and of the Suralaya power plant, 
West Java, Indonesia, both obtained for our previous study, were added for comparison [13,42]. Both fly ashes have been used extensively in other research as pozzolanic material in the concrete industry. According to ASTM C618 [43], the class of the fly ash can be indicated from the total $\mathrm{SiO}_{2}+\mathrm{Al}_{2} \mathrm{O}_{3}+\mathrm{Fe}_{2} \mathrm{O}_{3}$ content. Class $\mathrm{F}$ fly ash has more than $70 \%$ of these compounds, whereas class $\mathrm{C}$ has only $50 \%$. The total of $\mathrm{SiO}_{2}+\mathrm{Al}_{2} \mathrm{O}_{3}+\mathrm{Fe}_{2} \mathrm{O}_{3}$ for each of the Pacitan, Paiton, and Suralaya fly ash was $74.92 \%, 66.95 \%$, and $81.51 \%$, respectively. These results show that the fly ash sample of the Pacitan and Suralaya fly ash can be categorized as class F fly ash while the Paiton fly ash is class $\mathrm{C}$. The calcium oxide content of the Pacitan fly ash is one of the main interests as it could indicate a self-cementing property or flash setting potential of the fly ash in a geopolymer mixture. It was shown that Pacitan fly ash has calcium oxide content between the Paiton fly ash and Suralaya fly ash.

The loss on ignition (LOI) and the $\mathrm{SO}_{3}$ content should be less than $6 \%$ and $5 \%$, respectively, as stated in the ASTM C618 [43]. All the fly ash samples have much lower values compared to the requirement of the standard. This showed that these power plants have good burning processes and the fly ash samples taken from the source power plants could have good consistent quality.

Results of the rapid indicator tests for the fly ash, i.e., normal consistency, specific gravity, $\mathrm{pH}$, and particle fineness as measured by the percentage retained on $45 \mu \mathrm{m}$ sieve are reported in Table 6 . It was found that the normal consistency of Pacitan fly ash has the same value as the Paiton fly ash, which is 0.18 , and Suralaya fly ash has the highest value of 0.25. Compared to the OPC, the fly ash would reduce the water requirement of the mixture when used as cement replacement. The low water requirement on Pacitan fly ash indicates that the fly ash is sphericalshaped due to the pulverized coal combustion process. Furthermore, the low water requirements are also due to the low LOI. The $\mathrm{pH}$ indicates fly ash alkali content as mostly determined by the calcium oxide content. The change of $\mathrm{pH}$ is correlated to the change of the chemical content that could influence the chemical reaction in the mortar phase. If the $\mathrm{pH}$ of the fly ash is higher than 11, then the fly ash could have a self-cementing property and, consequently, there is a risk of flash setting when making geopolymer concrete [44].

The particle size analysis (PSA) of the OPC and fly ashes, and the particle size distributions are shown in Figure 2. It is shown that Pacitan fly ash has the smallest particle size compared to the OPC and other fly ash samples. The results are consistent with the percentage of particles retained on the $45 \mu \mathrm{m}$ sieve measured previously, showing that the sieve analysis can be used to replace the PSA test for rapid quality assurance. All three fly ash samples passed the ASTM C618 [43] standard, which requires less than $34 \%$ retained on the sieve.

From the tests, Pacitan fly ash shows excellent potential to be used as pozzolanic material substituting OPC in low or higher content, as a selfcementing material, as fly ash-calcium hydroxide binder, and as a geopolymer base material. This potential needs to be confirmed with mortar specimen testing.

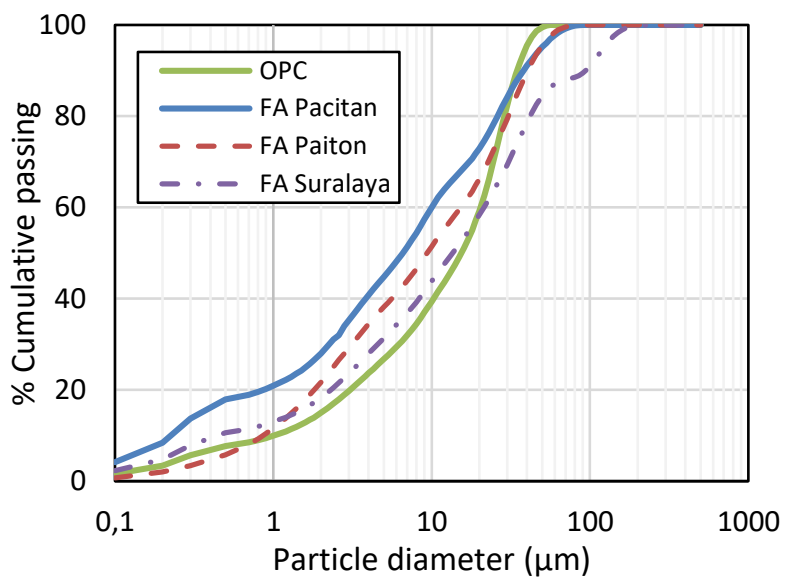

Figure 2. Particle Size Distribution of OPC and Three Fly Ash Samples

Table 5. Chemical Composition of Fly Ash from XRF Analysis (\% by mass)

\begin{tabular}{|c|c|c|c|c|c|c|c|c|c|c|c|c|}
\hline Material & $\mathrm{SiO}_{2}$ & $\mathrm{Al}_{2} \mathrm{O}_{3}$ & $\mathrm{Fe}_{2} \mathrm{O}_{3}$ & $\mathrm{CaO}$ & $\mathrm{MgO}$ & $\mathrm{Na}_{2} \mathrm{O}$ & $\mathrm{K}_{2} \mathrm{O}$ & $\mathrm{TiO}_{2}$ & $\mathrm{MnO}_{2}$ & $\mathrm{P}_{2} \mathrm{O}_{5}$ & $\mathrm{SO}_{3}$ & LOI \\
\hline FA Pacitan & 45.78 & 17.22 & 11.92 & 13.83 & 5.87 & 1.43 & 1.22 & 0.75 & 0.22 & 0.17 & 0.83 & 0.41 \\
\hline FA Paiton & 36.57 & 19.06 & 11.32 & 19.5 & 6.21 & 2.45 & 1.35 & 0.75 & 0.15 & 0.21 & 1.3 & 0.63 \\
\hline FA Suralaya & 45.21 & 28.06 & 8.24 & 6.83 & 3.09 & 3.27 & 1.39 & 0.84 & 0.16 & 0.28 & 0.58 & 1.58 \\
\hline
\end{tabular}

Table 6. Normal Consistency, Specific Gravity, pH, and Particle Fineness of OPC and Fly Ash

\begin{tabular}{lcccc}
\hline \multicolumn{1}{c}{ Material } & Normal Consistency & Specific Gravity & $\mathrm{pH}$ & \% Retained $45 \mu \mathrm{m}$ sieve \\
\hline OPC & 0.33 & 2.89 & 11.2 & 2.6 \\
FA Pacitan & 0.18 & 2.61 & 10.3 & 7.5 \\
FA Paiton & 0.18 & 2.76 & 12.0 & 8.1 \\
FA Suralaya & 0.25 & 2.35 & 9.4 & 19.2 \\
\hline
\end{tabular}




\section{Pozzolan Mortar}

Superplasticizer (SP) demand for each mortar mixture with different water-to-binder ratio is shown in Figure 3. The need for SP decreases with the addition of water and the increase of fly ash replacement ratio to achieve a workability target of flow diameter of $15 \pm 1 \mathrm{~cm}$ in the mortar flow table test. At higher w/b, SP was not needed in the mixture as the increased content of the fly ash also increases mortar mixture workability. The initial setting time of the mortar mixture is shown in Figure 4. The increase of initial setting time with the increase of fly ash content is already a recognized condition in pozzolan concrete. The lower w/b mixture should have a shorter initial set, but the use of SP to increase workability also prolongs the initial setting time of the mortar. Overall, the retardation effect of the fly ash in the pozzolan mortar was acceptable as the longest initial time in the $4 \mathrm{P}-30 \%$ mixture was about 260 minutes. Figure 5 shows the temperature increase of the paste mixture of the pozzolan mixture. The temperature increase correlated well with the initial setting time of the mortar mixture. The increase of $\mathrm{w} / \mathrm{b}$ in the mixture was found to lower the peak temperature of the paste mixture, but the time to reach the peak temperature was similar.

The compressive strength of the pozzolan mortar at various ages is shown in Figure 6. The strength of the mortar is mainly controlled by the w/b of the mixture. Therefore, the w/b should be targeted as low as possible for better compressive strength. The 3-day pozzolan mortar showed a reduction of strength with the increase of fly ash content. This result is more noticeable in w/b of 0.4 . However, with increase of time, the pozzolan mortar reached higher strength, similar to the control mortar.

The strength activity index (SAI) is calculated as the percentage of the compressive strength compared to the control mortar at the same testing age. ASTM C618 indicates that the fly ash with an acceptable pozzolan reactivity should have SAI higher than $75 \%$ for 7- and 28-day compressive strength. Table 7 shows the SAI of the pozzolan mortar with various w/b for the fly ash replacement ratio up to $30 \%$. Only at the $4 \mathrm{P}-30 \%$ code at 3 days was the SAI index less than $75 \%$. The SAI results show that most of the mixture can reach the same or even higher compressive strength than the control mortar and that the Pacitan fly ash has good pozzolanic reactivity.

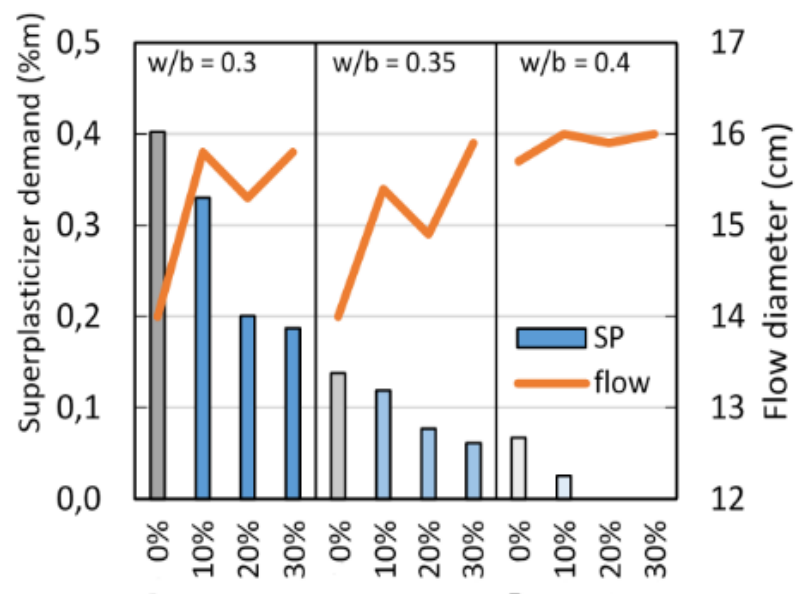

Fly Ash Content

Figure 3. Superplasticizer Demand of the Pozzolan Mortar

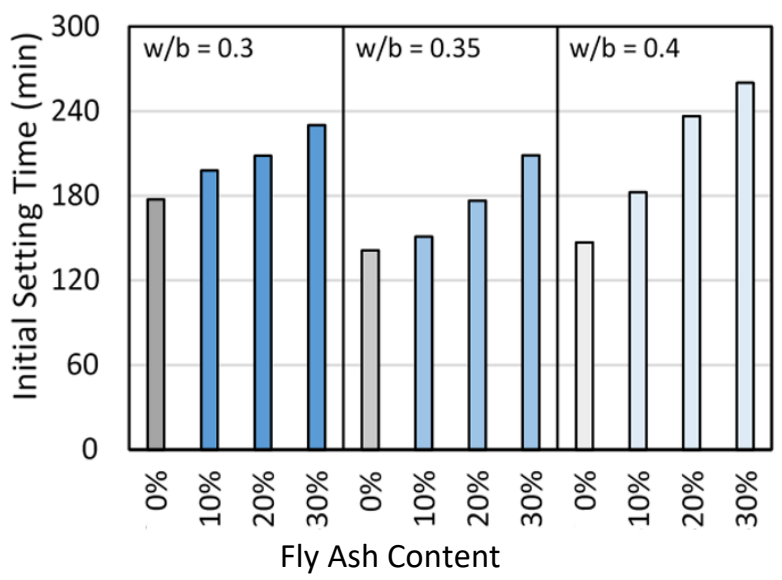

Figure 4. Initial Setting Time of the Pozzolan Mortar

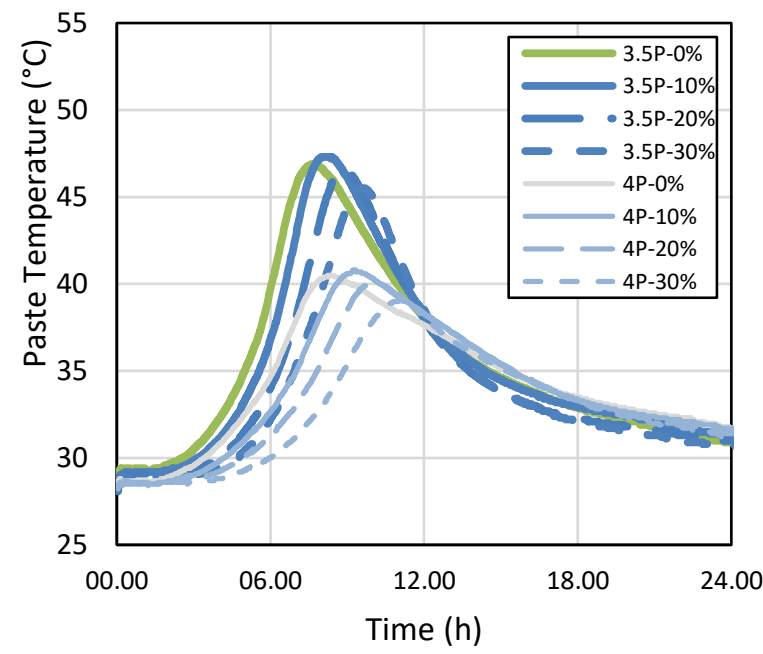

Figure 5. Temperature Evolution of the Paste with Variation of w/b 


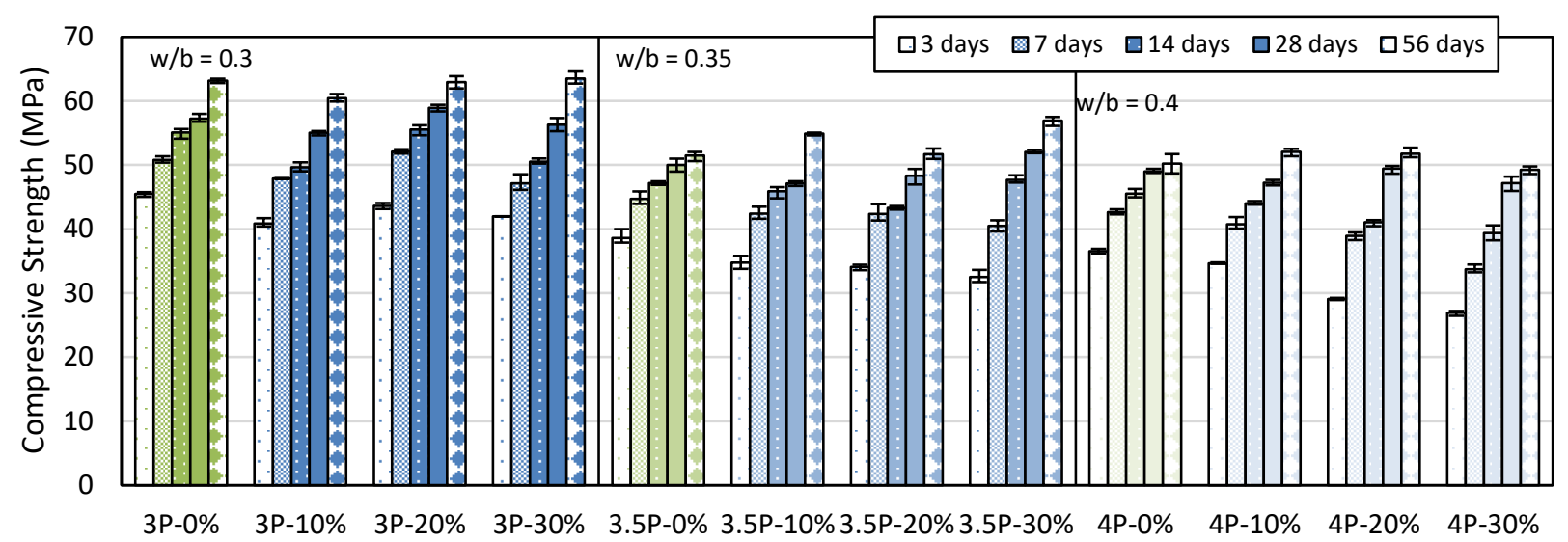

Figure 6. Compressive Strength of the Pozzolan Mortar

Table 7. Strength Activity Index (SAI) of Pozzolan Mortar with w/b of $0.3,0.35$, and 0.4

\begin{tabular}{lrrrrr}
\hline \multirow{2}{*}{ Code } & \multicolumn{5}{c}{ Strength Activity Index (\%) } \\
\cline { 2 - 6 } & $3 \mathrm{~d}$ & $7 \mathrm{~d}$ & $14 \mathrm{~d}$ & $28 \mathrm{~d}$ & $56 \mathrm{~d}$ \\
\hline $3 \mathrm{P}-0 \%$ & 100.0 & 100.0 & 100.0 & 100.0 & 100.0 \\
$3 \mathrm{P}-10 \%$ & 89.9 & 94.3 & 90.2 & 96.1 & 95.6 \\
$3 \mathrm{P}-20 \%$ & 95.8 & 102.6 & 100.9 & 103.0 & 99.6 \\
$3 \mathrm{P}-30 \%$ & 92.3 & 92.8 & 91.8 & 98.4 & 100.6 \\
\hline $3.5 \mathrm{P}-0 \%$ & 100.0 & 100.0 & 100.0 & 100.0 & 100.0 \\
$3.5 \mathrm{P}-10 \%$ & 90.0 & 94.8 & 97.3 & 94.2 & 106.6 \\
$3.5 \mathrm{P}-20 \%$ & 88.3 & 94.7 & 91.8 & 96.6 & 100.4 \\
$3.5 \mathrm{P}-30 \%$ & 84.3 & 90.6 & 101.1 & 104.1 & 110.6 \\
\hline $4 \mathrm{P}-0 \%$ & 100.0 & 100.0 & 100.0 & 100.0 & 100.0 \\
4P-10\% & 94.8 & 95.6 & 96.7 & 96.4 & 103.7 \\
4P-20\% & 79.6 & 91.3 & 90.2 & 100.9 & 103.1 \\
4P-30\% & 73.7 & 79.1 & 86.5 & 96.3 & 98.1 \\
\hline
\end{tabular}

High-volume Fly Ash and Self-cementing Mortar

SP demand for mortar mixtures with w/b of 0.3 for 0 $100 \%$ fly ash content is shown in Figure 7 . Higher fly ash content in the mixture benefits the mortar workability. SP demand decreased along with the increase in fly ash content. This is mainly because fly ash particles have a rounded shape and smaller size than cement. Fly ash can be distributed evenly into the mixture. Due to their zeta potential [45], fly ash particles act as dispersants and reduce the flocculation of cement particles. For the HVFA mortar mixture, the SP demand is less than $0.1 \%$, which is a very low dosage, and $\mathrm{SP}$ is no longer needed for the self-cementing mortar. The flow diameter of $15 \pm 1 \mathrm{~cm}$ can be achieved without the addition of superplasticizer.

Figure 8 shows the initial setting times of pozzolan, HVFA, and self-cementing mortar at w/b of 0.3 . The delayed setting time was expected due to slower reaction of the fly ash. Initial setting time of more than 4 hours was observed on the HVFA mortar. The initial setting time of the self-cementing mortar was observed more than 7 hours, with anomaly found for the $100 \%$ fly ash mortar. The reactivity of the calcium oxide in the mixture in the absence of OPC could contribute to this faster setting time. Fly ash with high $\mathrm{pH}$ needed to be observed more cautiously as it could link to the potential occurrence of flash setting.

The temperature raised in the paste with w/b of 0.3 is shown in Figure 9. The more fly ash content is added into the mixture, the longer it takes to reach its peak temperature and the lower the temperature rise. The heat of hydration from cement is the main source of thermal reaction. HVFA paste shows a reduced peak compared to the pozzolan paste. With more fly ash content in the mixture, the curve flattens. The selfcementing paste shows almost no increase of temperature and only a small bump at the beginning. These results show that for fly ash replacing cement content by $>90 \%$, the activation energy was not enough to increase the reactivity of the mixture. Without heating, the specimens take too long to harden. Although mortar specimens increase in strength at later age, the initial reaction rate is very slow. Therefore, for self-cementing mortar, curing was performed at elevated temperature of $60^{\circ} \mathrm{C}$ for 24 hours.

Figure 10 shows the compressive strength of mortar with fly ash substituting OPC from $0-100 \%$ at w/b of 0.3. It was shown that the initial compressive strength was reduced with the increase of fly ash content replacing OPC. However, at the later testing age, the strength is still increasing and can reach up to more than $50 \mathrm{MPa}$ for the HVFA mortar while the self-cementing mortar can reach compressive strength up to $25 \mathrm{MPa}$ and $12 \mathrm{MPa}$ for mixtures with $10 \%$ and $5 \%$ OPC, respectively. The 100\% fly ash mortar was shown to have a low self-cementing property, but it still can harden and tested at $2.7 \mathrm{MPa}$ at day 56 . The SAI of the mortar is shown in Table 8. 
At 50\% fly ash replacement ratio, the HVFA mortar still could meet the $75 \%$ requirement for 7 - and 28 day strength, whereas for the $60 \%$ and $70 \%$ replacement ratio it could only comply with the 28-day strength. This shows that HVFA mortar is still a very beneficial mixture as fly ash can reduce the cement and superplasticizer content in the mixture. The use of fly ash as a cement substitute with levels $>70 \%$ results in low compressive strength and will not meet the SAI requirement. However, the use of this mixture for non-structural application can be considered. Mixtures for non-structural or filling material can utilize very high-volume fly ash.

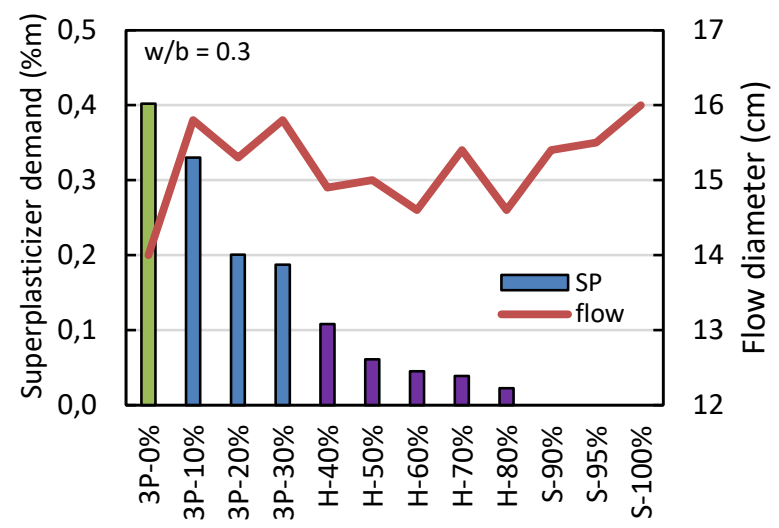

Figure 7. Superplasticizer Demand of the Mortar with Fly Ash Replacing OPC

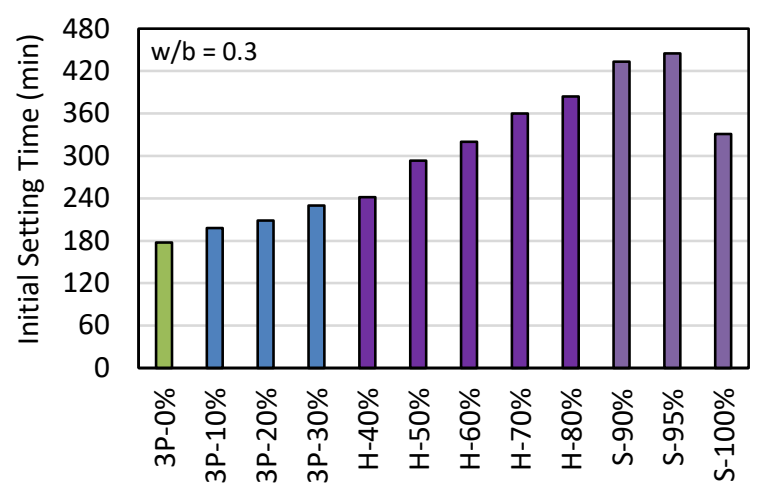

Figure 8. Initial Setting Time of the Mortar Mixture with Various Content of Fly Ash Replacing OPC

Table 8. Strength Activity Index (SAI) for pozzolan, HVFA, and self-cementing mortar at w/b 0.3

\begin{tabular}{lrrrrr}
\hline \multirow{2}{*}{ Code } & \multicolumn{5}{c}{ Strength Activity Index (\%) } \\
\cline { 2 - 6 } & $3 \mathrm{~d}$ & $7 \mathrm{~d}$ & $14 \mathrm{~d}$ & $28 \mathrm{~d}$ & $56 \mathrm{~d}$ \\
\hline 3P-0\% & 100 & 100 & 100 & 100 & 100 \\
3P-10\% & 89.9 & 94.3 & 90.2 & 96.1 & 95.7 \\
3P-20\% & 95.8 & 102.6 & 100.9 & 103.0 & 99.6 \\
3P-30\% & 92.3 & 92.8 & 91.8 & 98.3 & 100.6 \\
\hline H-40\% & 73.3 & 80.7 & 89.7 & 90.0 & 86.4 \\
H-50\% & 66.4 & 89.0 & 88.9 & 91.3 & 87.8 \\
H-60\% & 53.8 & 71.0 & 85.5 & 97.3 & 88.8 \\
H-70\% & 45.8 & 53.9 & 66.4 & 75.3 & 74.0 \\
H-80\% & 26.1 & 40.7 & 40.2 & 49.9 & 60.3 \\
\hline S-90\% & 9.9 & 15.5 & 21.1 & 37.5 & 41.1 \\
S-95\% & 5.0 & 6.9 & 9.9 & 17.3 & 19.2 \\
S-100\% & 0.0 & 0.0 & 3.9 & 4.9 & 4.4 \\
\hline
\end{tabular}

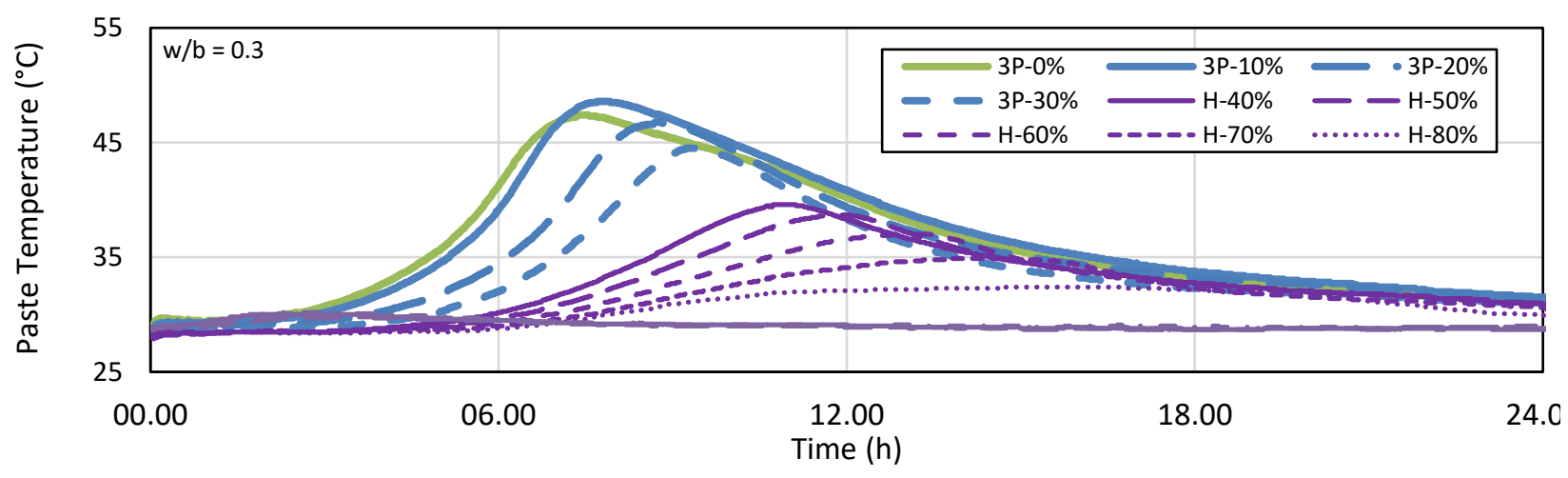

Figure 9. Temperature Evolution of the Paste for Various Cement Replacement Ratio.

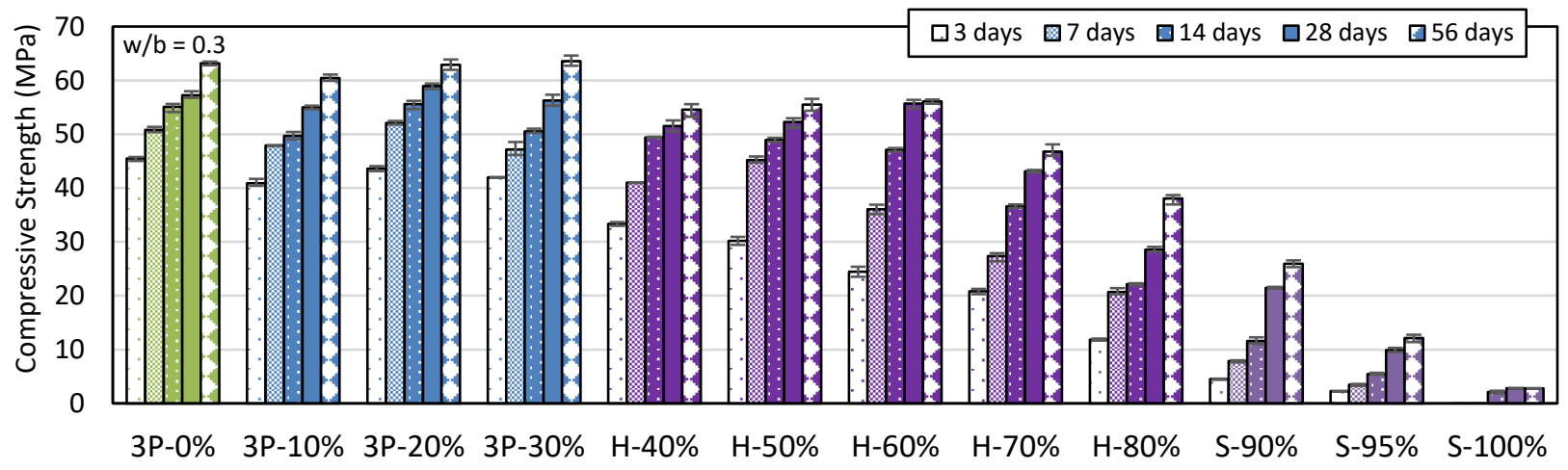

Figure 10. Compressive Strength of the Mortar at Various Cement Replacement Ratios 


\section{Fly Ash-Calcium Hydroxide Mortar}

The fly ash-calcium hydroxide ( $\mathrm{Fa}-\mathrm{Ca})$ binder was manufactured by reacting fly ash powder with calcium hydroxide $\left(\mathrm{Ca}(\mathrm{OH})_{2}\right)$ paste or dried powder. $\mathrm{Ca}(\mathrm{OH})_{2}$ was used at $30 \%, 35 \%$, and $40 \%$ of the total binder content. The $\mathrm{Fa}-\mathrm{Ca}$ binder was mixed at w/b of 0.4 due to the higher water requirement of the $\mathrm{Ca}(\mathrm{OH})_{2}$ in the mixture. The SP demand for the fresh mixture to reach the target flow diameter is shown in Figure . Although w/b is already higher than those of the pozzolan mortar, SP demand was significantly higher from $0.4 \%$ up to $1 \%$ of the binder content by mass. The need for SP increases with the increased content of the $\mathrm{Ca}(\mathrm{OH})_{2}$. Figure shows that the initial setting time of the $\mathrm{Fa}-\mathrm{Ca}$ mortar mixture is almost constant, irrespective of variation of the $\mathrm{Ca}(\mathrm{OH})_{2}$ content. The initial setting time measured was about 80 minutes, showing faster setting time compared to the previously discussed fly ash mortar. However, the temperature evolution of the $\mathrm{Fa}-\mathrm{Ca}$ paste as shown in Figure showed a very low increase in temperature, indicating insufficient activation energy to accelerate the reaction of fly ash and calcium hydroxide. Mortar specimens were put into a thermal curing regime of $60^{\circ} \mathrm{C}$ for 24 hours. Without thermal curing, the early-age strength would be low and the specimen could not be demolded for a few days.

The increase of compressive strength of the $\mathrm{Fa}-\mathrm{Ca}$ mortar is shown in Figure. The 100\% self-cementing mortar was also included for comparison. The use of calcium hydroxide in the mortar has a significant effect on the compressive strength compared to those of $100 \%$ fly ash mortar. The compressive strength of the $\mathrm{Fa}-\mathrm{Ca}$ mortar is also increased as the mortar ages. At 3 days, the $\mathrm{Ca}-35 \%$ and $\mathrm{Ca}-40 \%$ showed lower compressive strength results compared to $\mathrm{Ca}-30 \%$. However, it was found that the $\mathrm{Ca}-35 \%$ and $40 \%$ had higher long-term strength increase, with the Ca-40\% reaching $16.4 \mathrm{MPa}$. This result demonstrates that with more calcium hydroxide in the mortar, more C-S-H is formed, which results in higher compressive strength. Optimum $\mathrm{Ca}(\mathrm{OH})_{2}$ replacement should be around $30-40 \%$ for the $\mathrm{Fa}-\mathrm{Ca}$ binder as too much $\mathrm{Ca}(\mathrm{OH})_{2}$ could cause instability in the mixture and require a long time to convert into calcium carbonate.

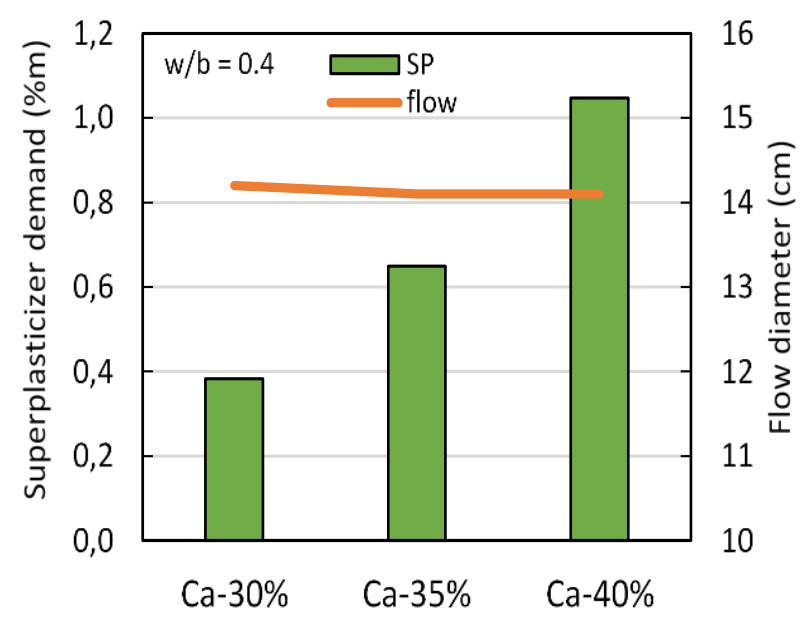

Figure 11. Superplasticizer Demand for the Fa-Ca Mortar

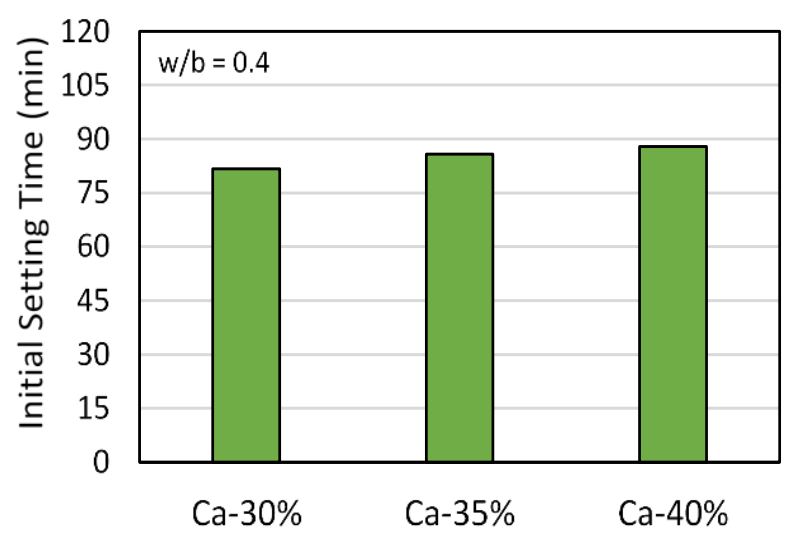

Figure 12. Initial Setting Time of the Fa-Ca Mortar

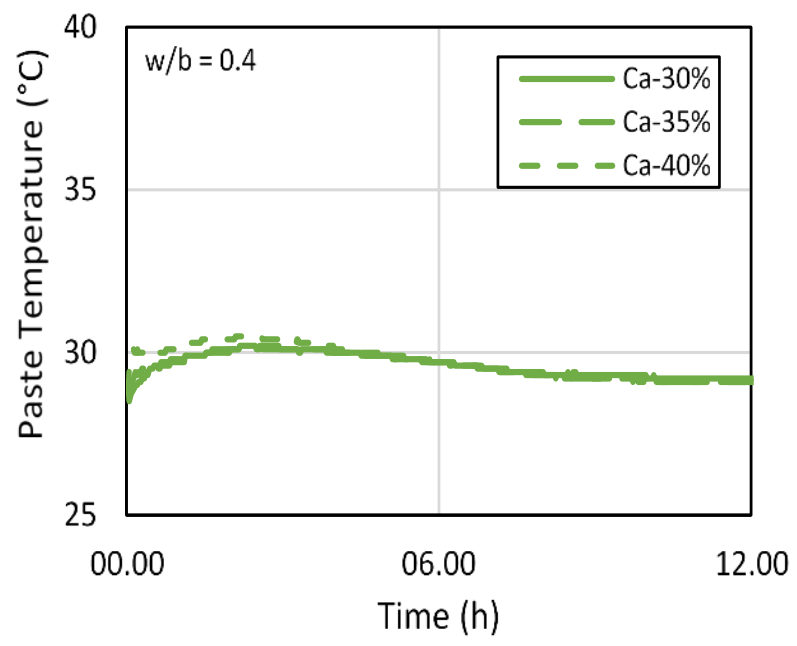

Figure 13. Temperature Evolution of the $\mathrm{Fa}-\mathrm{Ca}$ Paste Mixture 


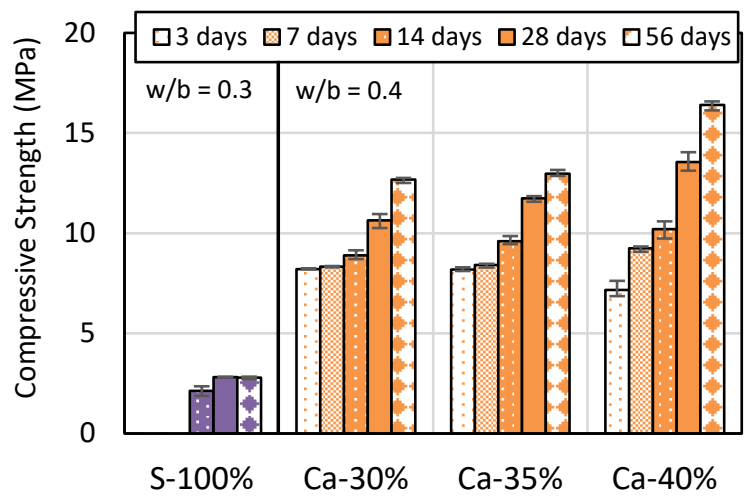

Figure 14. Compressive Strength of the Fa-Ca Mortar

\section{Geopolymer Mortar}

Fly ash-based geopolymer was studied extensively due to its potential as a high-strength concrete binder. The mixture proportion used was based on our previous study. Sodium hydroxide $(\mathrm{NaOH})$ solution $(8$ M) was found to be adequate to activate the fly ash, and the sodium silicate liquid $\left(\mathrm{Na}_{2} \mathrm{SiO}_{3}\right)$ to $\mathrm{NaOH}$ liquid ratio around 2-3 produced a stable geopolymer mortar. Figure shows the initial setting time of the geopolymer mortar made in this study. Higher $\mathrm{Na}_{2} \mathrm{SiO}_{3}$ to $\mathrm{NaOH}$ ratio reduces the initial setting time of the mortar. The function of sodium hydroxide $(\mathrm{NaOH})$ is to break down the $\mathrm{Al}$ and $\mathrm{Si}$ elements in fly ash to produce strong polymerization bonds [46]. Sodium silicate in the mortar acts to accelerate the polymerization reaction that occurs and its effect can be seen from the time needed to reach the initial setting $[14,47]$. The initial setting time of geopolymer is also strongly correlated with the calcium oxide content in the fly ash. When the geopolymer mortar can set on its own, the need for thermal curing can be omitted. However, the strength gain of the geopolymer could be slower. The current test was to investigate the potential of the fly ash as many studies had been done on the influence of fly ash variation, curing, and mixing conditions. Therefore, thermal curing was still applied to all the geopolymer specimens. Figure shows the increase in temperature in the paste mixture. There was an increase of temperature of about $7^{\circ} \mathrm{C}$ for the three mixtures. This showed that there is some activation energy of the fly ash to accelerate the geopolymer reaction. The results of the initial setting time and temperature increase are interrelated.

Figure shows the results of the compressive strength of the geopolymer mortar. All mortar specimens reached a relatively high 3-day compressive strength of more than $50 \mathrm{MPa}$. There is some increase in compressive strength for the later age for each mixture even though the increase is not high. This shows that the potential strength of the geopolymer mortar can be accelerated drastically by the thermal curing process. For the current fly ash, the $\mathrm{Na}_{2} \mathrm{SiO}_{3}$ to $\mathrm{NaOH}$ ratio of 2 seems to produce the highest strength.

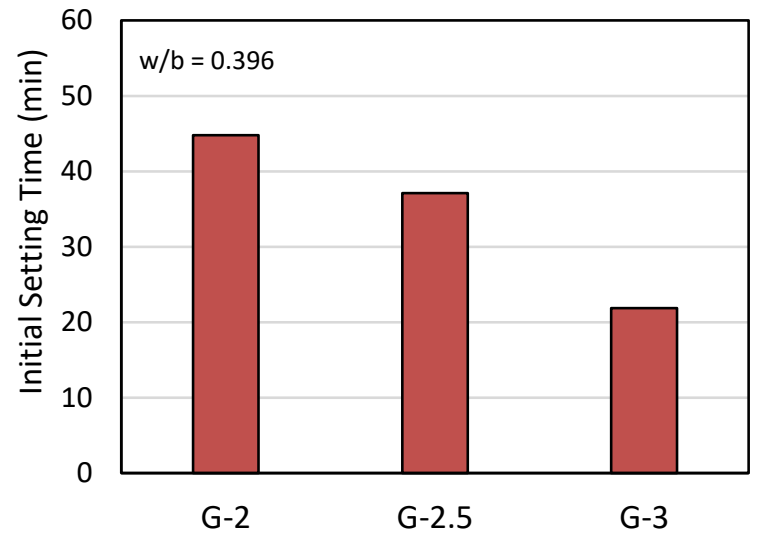

Figure 15. Initial Setting Time of the Geopolymer Mortar

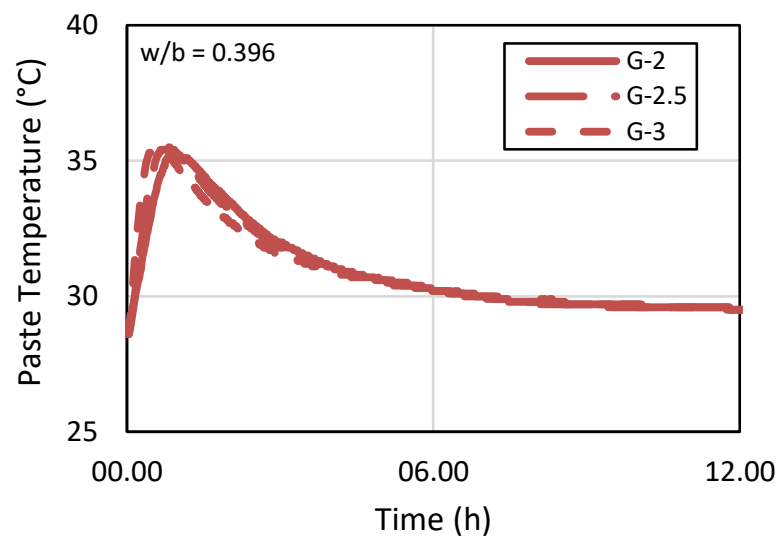

Figure 16. Temperature Evolution of the Geopolymer Paste

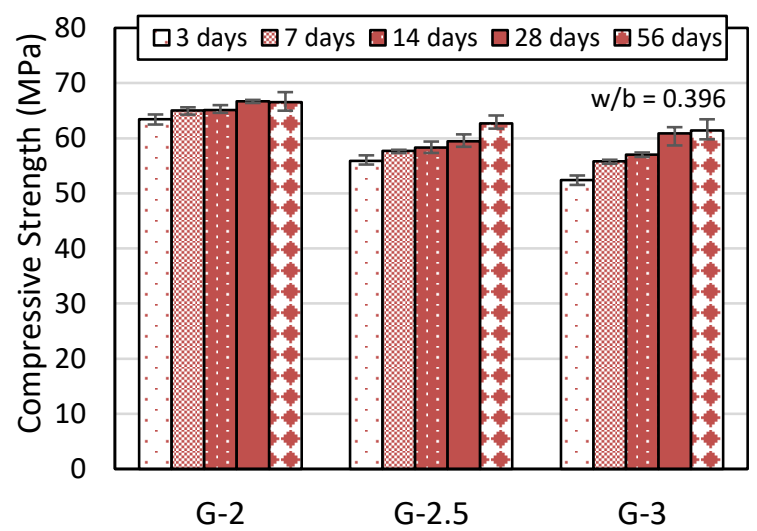

Figure 17. Compressive Strength of the Geopolymer Mortar

The correlations of bulk density and compressive strength for all the mortars are shown in Figure. It is shown that the binder system had significant effect on the density of the specimens and corresponding to their compressive strength. The pozzolan and HVFA mortars were found to have similar density of around $2150-2200 \mathrm{~kg} / \mathrm{m}^{3}$, with higher density at low w/b mixture. The $\mathrm{Fa}-\mathrm{Ca}$ mortar had the lowest bulk density due to higher $\mathrm{w} / \mathrm{b}$ and specific gravity of calcium hydroxide used. Geopolymer mortar was shown to have higher density because of different binder properties. 


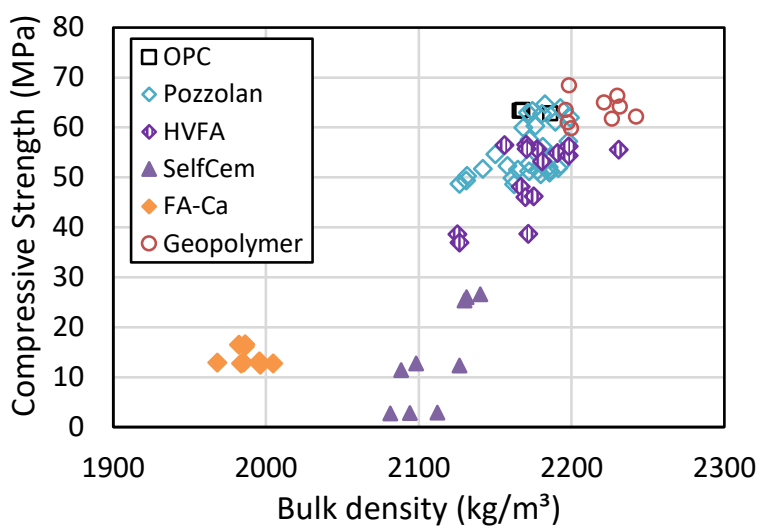

Figure 18. Compressive Strength of the Mortar as a Function of Bulk Density

\section{Conclusions}

The utilization of fly ash as a binder in concrete needs to be supported. However, the variation of quality and uncertainty of fly ash sources could hinder its wider use. This paper demonstrates an assessment model for determining fly ash quality for use as a binder in concrete. Some of the conclusions of this study are as follows:

1. The quality of fly ash depends on the power plant source. For the new sources of fly ash, the potential of fly ash to be used in pozzolan, HVFA, Fa-Ca binder, and geopolymer binder needs to be ascertained.

2. Variation of the fly ash quality with each delivery is one of the main problems for the application of a high replacement ratio. Rapid indicator tests, such as visual inspection, normal consistency, $\mathrm{pH}$, retained on $45 \mu \mathrm{m}$ sieve, can be used as simple tools to determine the consistency of fly ash quality.

3. The physical and chemical composition of fly ash from the Pacitan power plant meets the ASTM C618 standards. The sample qualified as class F fly ash with intermediate calcium content and fine particle size, low LOI, low $\mathrm{SO}_{3}$, and low water requirement. This fly ash can be used as partial or full replacement of OPC in concrete.

4. Reactivity of the Pacitan fly ash was determined experimentally in several binder systems in mortar specimens and the result needs to be extended into a concrete specimen. Considering the overall performance of the Pacitan fly ash, it can be used as pozzolan, HVFA, and geopolymer concrete with excellent results.

\section{References}

1. Cornot-Gandolphe, S., Indonesia's Electricity Demand and the Coal Sector: Export or Meet Domestic Demand?, The Oxford Institute for Energy Studies, 2017.
2. Ordonez, J.A., Jakob, M., Steckel, J.C., and Fünfgeld, A., Coal, Power and Coal-Powered Politics in Indonesia, Environmental Science \& Policy, 123, 2021, pp. 44-57, https://doi.org/10. 1016/j.envsci.2021.05.007.

3. Edwards, G.A.S., Coal and Climate Change, Wiley Interdisciplinary Reviews: Climate Change, 10, 2019, e607, https://doi.org/10.1002/wcc.607.

4. Fauzi, A., Nuruddin, M.F., Malkawi, A.B., and Abdullah, M.M.A.B., Study of Fly Ash Characterization as a Cementitious Material, Procedia Engineering, 148, 2016, pp. 487-493.

5. Ali, M.B., Saidur, R., and Hossain, M.S., A Review on Emission Analysis in Cement Industries, Renewable and Sustainable Energy Reviews, 15, 2011, pp. 2252-2261.

6. Ahmaruzzaman, M., A Review on the Utilization of Fly Ash, Progress in Energy and Combustion Science, 36, 2010, pp. 327-363.

7. Yao, Z.T., Ji, X.S., Sarker, P.K., Tang, J.H., Ge, L.Q., Xia, M.S., and Xi, Y.Q., A Comprehensive Review on the Applications of Coal Fly Ash, Earth-Science Reviews, 141, 2015, pp. 105-121.

8. Feng, X. and Clark, B., Evaluation of the Physical and Chemical Properties of Fly Ash Products for Use in Portland Cement Concrete, in: World Coal Ash Conference, 2011, pp. 1-8.

9. Wang, Z. and Song, Y., Adsorption Properties of CFBC Ash - Cement Pastes as Compared With PCC Fly Ash - Cement Pastes, International Journal of Coal Science \& Technology, 3, 2016, pp. 62-67, https://doi.org/10.1007/s40789-0160103-8.

10. Siddique, S. and Jang, J.G., Effect of CFBC Ash as Partial Replacement of PCC Ash in AlkaliActivated Material, Construction and Building Materials, 244, 2020, 118383.

11. Antoni, A., Gunawan, R., and Hardjito, D., Rapid Indicators in Detecting Variation of Fly Ash for Making HVFA Concrete, Applied Mechanics and Materials, 815, 2015, pp. 153-157, https://doi.org/ 10.4028/www.scientific.net/AMM.815.153.

12. Chen, H.J., Shih, N.H., Wu, C.H., and Lin, S.K., Effects of the Loss On Ignition of Fly Ash on the Properties of High-Volume Fly Ash Concrete, Sustainability, 11, 2019, 2704.

13. Antoni, A., Widianto, A.K., Wiranegara, J.L., and Hardjito, D., Consistency of Fly Ash Quality for Making High Volume Fly Ash Concrete, Jurnal Teknologi, 79, 2017, pp. 13-20, https://doi.org/ 10.11113/jt.v79.11870.

14. Antoni, A., Wijaya, S.W., and Hardjito, D., Factors Affecting the Setting Time of Fly AshBased Geopolymer, Materials Science Forum, 841, 2016, pp. 90-97, https://doi.org/10.4028/ www.scientific.net/MSF.841.90.

15. Antoni, Wibawa, H.S., and Hardjito, D., Influence of Particle Size Distribution of High Calcium Fly Ash on HVFA Mortar Properties, 
Civil Engineering Dimension, 20, 2019, pp. 5156, https://doi.org/10.9744/CED.20.2.51-56.

16. Rivera, F., Martínez, P., Castro, J., and López, M., Massive Volume Fly-Ash Concrete: a More Sustainable Material with Fly Ash Replacing Cement and Aggregates, Cement and Concrete Composites, 63, 2015, pp. 104-112, https://doi. org/10.1016/j.cemconcomp.2015.08.001.

17. Huang, C.H., Lin, S.K., Chang, C.S., and Chen, H.J., Mix Proportions and Mechanical Properties of Concrete Containing Very High-Volume of Class F Fly Ash, Construction and Building Materials, 46, 2013, pp. 71-78, https://doi.org/10. 1016/j.conbuildmat.2013.04.016.

18. Shaikh, F.U.A., Supit, S.W.M., and Sarker, P.K., A Study on the Effect of Nano Silica on Compressive Strength of High Volume Fly Ash Mortars and Concretes, Materials and Design, 60, 2014, pp. 433-442, https://doi.org/10.1016/ j.matdes.2014.04.025.

19. Rashad, A.M., A Brief on High-Volume Class F Fly Ash as Cement Replacement - A Guide for Civil Engineer, International Journal of Sustainable Built Environment, 4, 2015, pp. 278 306, https://doi.org/10.1016/j.ijsbe.2015.10.002.

20. Bentz, D.P. and Ferraris, C.F., Rheology and Setting of High Volume Fly Ash Mixtures, Cement and Concrete Composites, 32, 2010, pp. 265-270, https://doi.org/10.1016/j.cemconcomp. 2010.01.008.

21. Hoyos-Montilla, A.A., Puertas, F., and Tobón, J.I., Microcalorimetric Study of the Effect of Calcium Hydroxide and Temperature on The Alkaline Activation of Coal Fly Ash, Journal of Thermal Analysis and Calorimetry, 131, 2018, pp. 2395-2410.

22. Roskos, C., Cross, D., Berry, M., and Stephens, J., Identification and Verification of Self-Cementing Fly Ash Binders for " Green " Concrete, 2011 World of Coal Ash (WOCA) Conference, Colorado, USA, May 9-12, 2011.

23. Do, T.M., Kang, G.-O., and Kim, Y., Development of a New Cementless Binder for Controlled Low Strength Material (CLSM) Using Entirely ByProducts, Construction and Building Materials, 206, 2019, pp. 576-589.

24. Mackiewicz, S.M. and Ferguson, E.G., Stabilization of Soil With Self-Cementing Coal Ashes, World of Coal Ash (WOCA), Kentucky, USA, April 11-15, 2005, pp.1-7.

25. Cross, D., Stephens, J., and Vollmer, J., Structural Applications of 100 Percent Fly Ash Concrete, World Coal Ash (WOCA)., Kentucky, USA, April 11-15, 2005.

26. Gotti, E., Oleson, J.P., Bottalico, L., Brandon, C., Cucitore, R., and Hohlfelder, R.L., A Comparison of the Chemical and Engineering Characteristics of Ancient Roman Hydraulic Concrete With a
Modern Reproduction of Vitruvian Hydraulic Concrete, Archaeometry, 50, 2008, pp. 576-590.

27. Luxán, M.P. de, De Rojas, M.I.S., and Frías, M., Investigations on the Fly Ash-Calcium Hydroxide Reactions, Cement and Concrete Research, 19, 1989, pp. 69-80.

28. Biernacki, J.J., Williams, P.J., and Stutzman, P.E., Kinetics of Reaction of Calcium Hydroxide and Fly Ash, ACI Materials Journal, 98, 2001, pp. 340-349.

29. Hlaváček, P., Šulc, R., Šmilauer, V., Rößler, C., and Snop, R., Ternary Binder Made of CFBC Fly Ash, Conventional Fly Ash, and Calcium Hydroxide: Phase and Strength Evolution, Cement and Concrete Composites, 90, 2018, pp. 100-107, https://doi.org/10.1016/j.cemconcomp.2017.09.02 0.

30. Hardjito, D., Wallah, S.E., Sumajouw, D.M.J., and Rangan, B.V., Factors Influencing the Compressive Strength of Fly Ash-Based Geopolymer Concrete, Civil Engineering Dimension, 6, 2007, pp. 88-93, https://doi.org/10.9744/ced. 6.2.pp. 88-93.

31. Antoni, A., Wijaya, S.W., Satria, J., Sugiarto, A., and Hardjito, D., The Use of Borax in Deterring Flash Setting of High Calcium Fly Ash Based Geopolymer, Materials Science Forum, 857, 2016, pp. 416-420, https://doi.org/10.4028/www. scientific.net/MSF.857.416.

32. Antoni, A., Purwantoro, A.A.T., Suyanto, W.S.P.D., and Hardjito, D., Fresh and Hardened Properties of High Calcium Fly Ash-Based Geopolymer Matrix with High Dosage of Borax, Iranian Journal of Science and Technology Transactions of Civil Engineering, 44, 2020, pp.535-543, https://doi.org/10.1007/s40996-01900330-7.

33. Mustafa, M., Bakri, A., Mohammed, H., Kamarudin, H., Niza, I.K., Zarina, Y., Bakri, M. Al, and Mohammed, H., Review on Fly Ash-Based Geopolymer Concrete Without Portland Cement, Journal of Engineering and Technology Research, 3, 2011, pp. 1-4.

34. Wattimena, O.K., Antoni, A., and Hardjito, D., A Review on The Effect of Fly Ash Characteristics and Their Variations on the Synthesis of Fly Ash Based Geopolymer, AIP Conference Proceedings, 1887, 2017, https://doi.org/10.1063/1.5003524.

35. Antoni, A., Wijaya, S.W., and Hardjito, D., Factors Affecting the Setting Time of Fly AshBased Geopolymer, Materials Science Forum, 841, 2016, pp. 90-97, https://doi.org/10.4028/ www. scientific.net/MSF.841.90.

36. ASTM C778, Standard Specification for Sand, 14, 2014, pp. 1-3, https://doi.org/10.1520/C077813.2 .

37. ASTM D5239, Standard Practice for Characterizing Fly Ash for Use in Soil Stabilization, 
ASTM International, West Conshohocken, PA, 2012, https://doi.org/10.1520/D5239-04.2.

38. ASTM C187, Standard Test Method for Amount of Water Required for Normal Consistency of Hydraulic Cement Paste, ASTM International, West Conshohocken, PA, 2016, https://doi.org/ 10.1520/C0187-16.

39. ASTM C1437, Standard Test Method for Flow of Hydraulic Cement Mortar, ASTM International, West Conshohocken, PA, 2012, https://doi.org/ 10.1520/C1437-07.2.

40. ASTM C403, Standard Test Method for Time of Setting of Concrete Mixtures by Penetration Resistance, ASTM International, West Conshohocken, PA, 2016, https://doi.org/10.1520/ C0403_C0403M-16.

41. ASTM C109, Standard Test Method for Compressive Strength of Hydraulic Cement Mortars, ASTM International, West Conshohocken, PA, 2013.

42. Antoni, Wijaya, S.W., and Hardjito, D., Compressive Strength of Geopolymer Based on the Fly Ash Variation, Materials Science Forum, 841, 2016, pp. 98-103, https://doi.org/10.4028/www. scientific.net/MSF.841.98.
43. ASTM C618, Standard Specification for Coal Fly Ash and Raw or Calcined Natural Pozzolan for Use in Concrete, ASTM International, West Conshohocken, PA, 2012, https://doi.org/10.1520/ C0618.

44. Antoni, A., Satria, J., Sugiarto, A., and Hardjito, D., Effect of Variability of Fly Ash Obtained from the Same Source on the Characteristics of Geopolymer, MATEC Web Conference, 2017, pp. 9-13, https://doi.org/https://doi.org/10.1051/ matecconf/20179701026.

45. Termkhajornkit, P. and Nawa, T., The Fluidity of Fly Ash-Cement Paste Containing Naphthalene Sulfonate Superplasticizer, Cement and Concrete Research, 34, 2004, pp. 1017-1024, https://doi. org/10.1016/j.cemconres.2003.11.017.

46. Rifaai, Y., Yahia, A., Mostafa, A., Aggoun, S., and Kadri, E.H., Rheology of Fly Ash-Based Geopolymer: Effect of $\mathrm{NaOH}$ Concentration, Construction and Building Materials, 223, 2019, pp. 583-594.

47. Aupoil, J., Champenois, J.B., de Lacaillerie d'Espinose, J.B., and Poulesquen, A., Interplay Between Silicate and Hydroxide Ions During Geopolymerization, Cement and Concrete Research, 115, 2019, pp. 426-432. 